\title{
HOT CARGO CLAUSES: THE SCOPE OF SECTION 8(e)*
}

IN 1959 Congress amended the National Labor Relations Act to outlaw the hot cargo clause in labor contracts. ${ }^{1}$ A hot cargo clause generally takes the form of a contractual provision whereby the employer agrees not to discharge or discipline any employee for refusing to handle goods received from an "unfair company." The National Labor Relations Board recently held that certain clauses violated section $8(\mathrm{e})$-the section outlawing hot cargo clauses - even though the language of the clauses was not congruent to the prohibitory language of the statute. ${ }^{3}$ This holding may indicate that section 8 (e) will be broadly construed to cover any contractual limitation on an employer's dealings with other employers. Before such a construction becomes entrenched as part of the national labor law, it must be determined whether so far reaching a restriction on the right of labor and management to contract is necessary to effectuate the purposes of Congress as manifested in the language of the Act.

*Amalgamated Lithographers Union, 47 L.R.R.M. 1374 (1961).

1. It shall be an unfair labor practice for any labor organization and any employer to enter into any contract or agreement, express or implied, whereby such employer ceases or refrains or agrees to cease or refrain from handling, using, selling, transporting or otherwise dealing in any of the products of any other employer, or to cease doing business with any other person, and any contract or agreement entered into heretofore or hereafter containing such an agreement shall be to such extent unenforceable and void: Provided, That nothing in this subsection (e) shall apply to an agreement between a labor organization and an employer in the construction industry relating to the contracting or subcontracting of work to be done at the site of the construction, alteration, painting, or repair of a building, structure, or other work: Provided further, That for the purposes of this subsection (e) and section 8(b) (4) (B) the terms "any employer," "any person engaged in commerce or an industry affecting commerce," and "any person" when used in relation to the terms "manufacturer," "any other producer, processor, or manufacturer," "any other employer," or "any other person" shall not include persons in the relation of a jobber, manufacturer, contractor, or subcontractor working on the goods or premises of the jobber or manufacturer or performing parts of an integrated process of production in the apparel and clothing industry: Provided further, That nothing in this Act shall prohibit the enforcement of any agreement which is within the foregoing exception.

73 Stat. 543-44 (1959), 29 U.S.C. § 158(e) (Supp. II 1961).

2. Local 1976, United Bhd. of Carpenters v. NLRB, 357 U.S. 93, 112 (1958) (dissenting opinion); Farmer, The Status and Application of the Secondary-Boycott and Hot-Cargo Provisions, 48 Geo. L.J. 327, 336 (1959) ; Fenton, 'Hot-Cargo' and the Taft-Hartley Act, 31 Rocky MT. L. Rev. 153-54 (1959); NLRB, Legislative History of the LaboR Managearent Reporting and Disclosure Act 1325, 1386 (1959) [hereinafter cited as LeGis. Hist.] ; 7 LAB. REL. REP. [563; L.R.X.].

Companies labeled "unfair" are generally those which employ non-union labor, whose wages or working conditions are below union standards, or whose workers are on strike. 7 LAB. REL. REP. [563; L.R.X.].

3. Amalgamated Lithographers Union, 47 L.R.R.M. 1374 (1961). 
In 1947 Congress enacted section 8(b) (4) - the so-called secondary boycott provision of the Taft-Hartley Act-which made it an unfair labor practice for a union to engage in, or to encourage employees to engage in, a strike or concerted refusal to handle goods or perform services with the object of forcing or requiring an employer to cease doing business with another employer. ${ }^{4}$ However, the hot cargo clause provided the union with a tool which in most cases would have the effect of forcing employers not to handle the products of certain other companies and yet might avoid violating the secondary boycott provision. The Board soon confirmed the union position, holding that neither the inclusion of a hot cargo clause in a contract, nor its enforcement by a union-inspired refusal to handle the hot cargo violated $8(\mathrm{~b})(4)$. It reasoned that the employer had voluntarily accepted the hot cargo clause and therefore the union action was not a "forcing or requiring" within the meaning of the statute. $^{5}$ In 1954, however, the Board partially reversed its earlier position by holding that the presence of a hot cargo clause in a contract did not preclude a finding that the union violated 8 (b) (4) by instructing its members to refrain from handling goods covered by the clause. ${ }^{6}$ The Supreme Court approved this position in the Sand Door decision, ${ }^{7}$ reasoning that the freedom guaranteed to the employer by 8 (b) (4)-the freedom to choose whether or not he will handle the goods of another employer-was intended to attach not simply at the time of the signing of the contract, but rather at any time the employer is faced with such a decision. Thus the fact that the employer has voluntarily agreed to the hot cargo clause at the bargaining table is not determinative. ${ }^{8}$

Even though, subsequent to Sand Door, hot cargo clauses constituted no defense to an 8 (b) (4) charge, they may have continued to be of some value in circumventing the purpose of that section. Since the Sand Door Court implicitly denied that the inclusion in the contract of a hot cargo clause con-

4. 61 Stat. 141-42 (1947), 29 U.S.C. § 158(b) 4 (1958).

5. International Bhd. of Teamsters (Conway's Express), 87 N.L.R.B. 972, 982-83 (1949). See also Chauffeurs Union, 105 N.I.R.B. 740 (1953), aff'd sub nom. Rabouin v. NLRB, 195 F.2d 906 (2d Cir. 1952). This position was adopted by the Second and District of Columbia Circuits. Rabouin v. NLRB, 195 F.2d 906, 911-12 (2d Cir. 1952) ; Milk Drivers Union v. NLRB, 245 F.2d 817 (2d Cir. 1957), rev'd, 357 U.S. 345 (1958); General Drivers Union v. NLRB, 247 F.2d 71 (D.C. Cir. 1957), modified, 357 U.S. 93 (1958). Cf. Local 1976, United Bhd. of Carpenters v. NLRB, 357 U.S. 93, 98-99 (1958).

6. International Bhd. of Teamsters, 110 N.L.R.B. 1769, 1777-86 (1954). The Board reaffimed this position in the Sand Door case, which involved a situation where union officers had instructed members of the carpenters' union not to hang certain doors which had been manufactured in a non-union shop. The Board held that in spite of the fact that the contract under which the carpenters were working contained a clause providing that "workmen will not be required to handle non-union material," the union was guilty of a violation of S(b) (4). Local 1976, United Bhd. of Carpenters, 113 N.L.R.B. 1210 (1955), aff'd sib nom. NLRB v. Local 1976, United Bhd. of Carpenters, 241 F.2d 147 (9th Cir. 1957), aff'd, 357 U.S. 93 (1958).

7. Local 1976, United Bhd. of Carpenters v. NLRB, 357 U.S. 93 (1958).

8. Id. at 105. 
stituted an unfair labor practice, ${ }^{9}$ and explicitly refrained from deciding whether such a clause retained any legal effect, ${ }^{10}$ it might be argued that in the event of an employer's breach of the clause, the union could sue for damages-if any could be shown-and possibly for specific performance. ${ }^{11}$ Also, the Court asserted that there would be no violation of 8 (b) (4) if the employer voluntarily adhered to the clause. ${ }^{12}$ Considerations of this sort led Congress to conclude that even subsequent to Sand Door, the hot cargo clause constituted a definite, if not fully ascertainable, loophole in $8(\mathrm{~b})(4) \cdot{ }^{13}$ The passage of section $8(\mathrm{e})$, which outlawed "any contract or agreement, express or implied" that an employer will not deal with other employers, ${ }^{14}$ was an attempt to close this loophole.

An early case arising under 8(e) was Amalgamated Lithographers Union. ${ }^{15}$ In bargaining with the Employing Lithographers, an employer's association, the union demanded that the association agree to the inclusion of certain

9. "A voluntary employer boycott does not become prohibited activity simply because a hot cargo clause exists." Id. at 107.

10. It does not necessarily follow from the fact that the unions cannot invoke the contractual provision in the manner in which they sought to do so in the present cases that it may not, in some totally different context not now before the Court, still have legal radiations affecting the relations between the parties. All we need now say is that the contract cannot be enforced by the means specifically prohibited Id. at 108 . in $\S 8(\mathrm{~b})(4)(\mathrm{A})$.

11. Section 301 (a) of the Taft-Hartley Act, 61 Stat. 156 (1947), 29 U.S.C. § 185(a) (1958) provides: "Suits for violation of contracts between an employer and a labor organization representing employees ... may be brought in any district court . ..." The success of a suit for breach of a hot cargo clause, particularly one seeking specific performance, is not certain, however, for a union victory would seem to run contrary to the rationale of Sand Door, in that its effect would be to force the employer to abide by the clause. See Apex Lumber Corp., 179 N.Y.S.2d 503 (Sup. Ct. Suffolk County 1958), where the court did decline specifically to enforce a hot cargo clause. See Cox, Labor Decisions of the Supreme Court at the October Term, 1957, 44 VA. L. Rev. 1057, 1090-91 (1958); The Supreme Court, 1957 Term, 72 HARv. L. Rev. 77, 142 (1958); Annot., 2 L. Ed. 2d 2097, 2101 (1958). But see Jones, Specific Enforcement of "Hot Cargo" Provisions in Collective Bargaining Agreements by Arbitration and Under Section 301(a) of the Taft-Hartlcy Act, 6 U.C.L.A.L. REv. 85 (1959).

12. 357 U.S. at 108.

The employer would surely be under pressure to adhere to the clause, for if he did not, he could expect the union to be more demanding at the next bargaining session. Cox, The Landrum-Griffin Amendments to the National Labor Relations Act, 44 Minn. L. REv. 257, 272 (1959).

A more important consideration, and one peculiarly within the cognizance of the Board because of its closeness to and familiarity with the practicalities of the collective bargaining process, is the possibility that the contractual provision itself may well not have been the result of choice on the employer's part free from the kind of coercion Congress has condemned.

357 U.S. at 106.

13. LEGrs. Hist. $475,1007,1651,1829$.

14. See note 1 supra.

15. 47 L.R.R.M. 1374 (1961). 
clauses in the contract, among them a "refusal to handle" clause and a "trade shop" clause. When the association refused to accept the controversial clauses, the union struck. ${ }^{10}$ The pivotal issue in the case was whether the proposed clauses violated $\mathrm{S}(\mathrm{e})$; if so, the strike was an unfair labor practice under $S$ (b) (4), which, as amended, prohibits striking with the object of forcing employer acceptance of a clause in violation of $8(\mathrm{e}) .{ }^{17}$ The proposed refusal to handle clause provided:

The Employers agree that they will not discharge, discipline or discriminate against any employee because such employee refuses to handle any lithographic production work which was made in a shop not under contract with the Amalgamated Lithographers of America. . . 18

The union argued that this clause was merely an agreement that employees as individuals need not work on the products of "unfair employers," whereas S(e) bans agreements that an employer will not handle the products of another employer. ${ }^{19}$ Although the Board did not specifically reject this contention, it held the clause illegal, because it was part of a total scheme devised to circumvent $S(\mathrm{e}) .20$

The other clause presenting a significant legal issue, ${ }^{21}$ the trade shop clause, read:

The parties agree that all the terms of this contract have been negotiated on the assumption that all lithographic production work will be done under approved union wages and conditions. In the event any employer covered by this contract requests any employee to handle any lithographic production work made in any shop which was not under contract with the Amalgamated Lithographers of America ... then the union in its dis-

16. Id. at $1375-76$.

17. Section $8(b)$ (4) provides:

It shall be an unfair labor practice for a labor organization ... to engage in . . . a strike ... where ... an object thereof is : (A) forcing or requiring any employer ... to enter into any agreement which is prohibited by section $8(\mathrm{e}) \ldots$

73 Stat. 542-43 (1959), 29 U.S.C. § 158(b) 4 (Supp. II 1961).

18. 47 L.R.R.M. at 1376.

19. Respondents' Exceptions to the Intermediate Report and Recommended Order and Rulings of the Trial Examiner and Brief, pp. 48-50, Amalgamated Lithographers Union, 47 L.R.R.M. 1374 (1961) [hereinafter cited as Respondent's Brief].

20. 47 L.R.R.M. at 1379 .

21. In addition to the refusal to handle and trade shop clauses, the union bargained for "struck work" and "chain shop" clauses. The union's claim with regard to these latter clauses was that they were mere contractual affirmations of the union's rights under the "ally doctrine." The Board held that the language of the clauses was overly broad, that it allowed the employees to refuse to handle goods which the ally doctrine did not give them the right to refuse to handle, and that therefore the clauses were hot cargo clauses in violation of $8(\mathrm{e}) .47$ L.R.R.M. at 1378-79. See also the $\S 10(l)$ proceeding, Brown v. Local 17, Amalgamated Lithographers, 180 F. Supp. 294, 300-01 (N.D. Cal. 1959). Both clauses appear to be examples of purposeful ambiguity. Had the draftsman of the clauses merely wanted to embody the ally doctrine, he could easily have done so; the Miami local of the same union did draw up unambiguous struck work and chain shop clauses, which the Board held not to violate 8(e). Amalgamated Lithographers Union, 47 L.R.R.M. 1380 (1961). 
cretion ... may reopen the contract as to that employer for negotiations as to the whole or any part thereof. In the event of a failure to agree on all terms within ten days after such re-opening, the Union shall have the right to terminate the contract forthwith as to that employer. . . .22

The union's position was that this clause is not prohibited by $8(\mathrm{e})$ because it explicitly leaves the employer the option of handling goods from non-union shops, and is merely intended to alleviate the hardship which would result to the union from such action. The union argued that in view of the special circumstances of the lithographic industry, commencement of subcontracting to non-union shops by the employer would have had a serious impact upon the economic and welfare needs of the union membership if the other provisions of the contract were to remain in force. ${ }^{23}$ Thus it was argued that the trade shop clause was designed "to achieve. . . a legitimate bargaining end and not to effectuate a boycott."24 But again, the Board held this clause to be part of an illegal scheme, reasoning that an employer faced with the possibility of union termination of the contract would in fact have no real option; he would be bound not to handle non-union goods. ${ }^{25}$

The Board was correct in holding that the refusal to handle clause considered in conjunction with the trade shop clause constituted no more than a thinly veiled implied agreement contrived in an effort to circumvent $8(e)$. Indeed, under the circumstances of the case, ${ }^{26}$ any provision modeled after the refusal to handle clause should, by itself, have been held illegal. First, such a provision falls comfortably within the proscriptive language of the

22. 47 L.R.R.M. at 1375 .

23. Respondent's Brief 11-37.

24. Id. at 17 .

25. 47 L.R.R.M. at 1377-78.

Considered in the light of human nature and practical realities of labor management relations, there exists such intimacy of relation between an employer's valuable contract position and operating situation on the one hand, and his decision to refrain from doing business with other employers on the other hand, that such choice as he may exercise is not free, but forced.

Brown v. Local 17, Amalgamated Lithographers, 180 F. Supp. 294, 303 (N.D. Cal. 1960).

26. David Previant, Counsel for the Teamsters Union and other labor organizations, argues that the factors present in the trucking industry imply that a refusal to handle clause would not be illegal in that industry:

In the transportation industry, for example, an employer can continue to do business with and handle the products of a nonunion establishment through the use of supervisory employees or other nonunion help. An agreement, therefore, protecting the right of individual employees to refuse to handle such products is not an agreement whereby the "employer" agrees to "cease or refrain" from handling such products.

Previant, The New Hot-Cargo and Secondary-Boycott Sections: A Critical Analysis, 48 GEo. L.J. 346, 355 (1959).

Even assuming the force of this argument with respect to the trucking industry, it cannot be carried over to the present case, since all those working for the employers in question who are qualified to do the work are probably members of the Amalgamated Lithographers. Respondent's Brief 19-21. 
statute ${ }^{27}$ because, despite its articulated emphasis on employee discretion, it is of necessity an implied agreement by the employer that he will "refrain from handling" hot cargo. For in agreeing to such a clause the employer would preclude himself from exercising effective control over any future decision to handle or not to handle hot goods; such control would be transferred to the union, which could, without fear of employer reprisal against the employees, decide whether or not to instruct its members to handle such goods. Furthermore, the clause falls not only within the statutory language, but within the clearly articulated purpose of Congress as well. Section $8(e)$ was designed to outlaw "all hot cargo clauses"28; and since the refusal to handle clause is identical to the typical pre-Landrum-Griffin hot cargo clause, ${ }^{29}$ Congress surely intended it to fall within $S(\mathrm{e})$.

Although the Board, by dealing with the clauses in issue as a unit, avoided passing upon the legality of the trade shop clause alone, its holding in a companion case ${ }^{30}$ indicates that any single clause permitting the union to terminate the contract in the event of employer handling of hot cargo would have been held illegal. In many cases the Board would be justified in equating a trade shop clause with an implied agreement not to handle, for to a given employer the real threat of union termination of an existing contract in the event of his handling hot goods may be so severe that his signing of the clause is clearly no less than a veiled advance agreement not to handle such goods. ${ }^{31}$ But it would be a mistake to conclude that in every case, an agreement which permits reopening of the contract when hot goods are handled by the employer is equivalent to an implied agreement of the type proscribed by $8(\mathrm{e})$. In a given industry at a particular time, for example, the bargaining strength of the employer may exceed the bargaining strength of the union to a degree sufficient to indicate to the employer that the union probably will not exercise its contractual discretion to reopen, and to assure him that even if it did he would have no reason to fear the consequences. In such a case the employer would feel relatively free to choose to handle hot goods; it cannot be said, therefore, that his agreement to permit reopening is an implied agreement not to handle. The Trial Examiner in the present case excluded union evidence that under the predecessor trade shop clause, which also contained a reopening provision, the union had never exercised its discretion despite instances of employer

27. See note 1 supra.

28. Legis. Hisr. $1454,1549,1568$.

29. See authorities cited at note 2 sipra.

30. Amalgamated Lithographers Union, 47 L.R.R.M. 1380, 1384 (1961) (holding that a clause identical to the trade shop clause was illegal in itself).

31. It is very hard for a trucking firm either to resist the Teamsters' demand for a hot cargo clause in collective bargaining, when the price of resistance would undoubtedly be a strike for still higher wages, or to refuse to live up to the contract once it has signed it, when the cost of non-compliance would undoubtedly be the Teamsters' insistence that the contract had been terminated by the violation, thus freeing the union to present new demands in collective bargaining.

LEGIS. HIST. 1708. 
handling of hot goods..$^{32}$ The excluded evidence might have indicated that both contracting parties fully understood that the union would almost certainly not exercise its discretion to reopen, and therefore that the clause was not a disguised agreement not to handle. The evidence in question was probably excluded because it could not have proved that the clause placed no possible limitation upon the employer's freedom to handle hot goods; it could, however, have indicated the degree to which the clause could have curtailed such freedom. The exclusion therefore suggests that the Board, in adopting the Trial Examiner's report, was not concerned with degrees of freedom; it was operating under the assumption that 8(e) represents a grant of absolute employer freedom.

The seeds of this view, espoused by commentators ${ }^{33}$ and observable in the present case, portend a construction of $8(\mathrm{e})$ under which any contractual provision which to any degree may have the effect of discouraging an employer's decision to deal with other employers will be struck down. It cannot be doubted that the legislative history of $8(\mathrm{e})$, when read in the context of Sand Door, reveals a desire to grant the employer a freedom to choose with whom he will deal. ${ }^{34}$ But that it reveals a desire to grant him absolute freedom, unhampered not only by "hot cargo clauses," but also by any and all clauses which might in some small manner incline him toward not handling hot goods, is a view unsupported by a reading of all the relevant history. ${ }^{35}$ Indeed, the complex of statutory language provides support for the view that Congress did not intend an absolute immunization of employers from union attempts to prevent them from dealing with other employers. Congress proscribed only union threats, coercion, or restraint of the employer (in addition to express or implied agreements) not to handle hot goods; it did not proscribe union attempts to induce or chlcourage the employer not to handle such goods. ${ }^{36}$ That it could have so im-

32. Respondent's Brief $18,29$.

33. In the final analysis it would seem that any contractual provision which attempts to restrict an employer in his dealings with certain employers merely because these employers are not on good terms with the contracting union will be held to violate 8(e). Such provisions meet the general requirements for a "hot-cargo" agreement; they are agreements whereby an employer consents in advance to boycott any $\mathrm{em}-$ ployer whom the union may designate as "unfair." This is just the type of secondary pressure which Congress sought to eliminate.

Comment, 45 CORNELL L.Q. 724, 750 n.126 (1960).

34. LEGIS. HIST. 1007, 1568.

35. But see Senator Morse's criticism:

The House bill, and now the conference report, have made it an unfair labor practice for any employer and a union to include in their agreement, a provision which imposes any condition upon doing business with another employer.

Legrs. HIST. 1428.

It is enlightening to note that Morse, the only Congressman verbalizing such an extreme intrepretation of $8(e)$, was one of the two Senators who voted against the final bill. LEGIs. Hisr. 1453.

36. Sec. 704. (a) Section 8(b) (4) of the National Labor Relations Act, as amended, is amended to read as follows:

(4) (i) to engage in, or to induce or encourage any individual employed by any per- 
munized the employer is demonstrated by section $8(b)(4)(i)$, where such inducement or encouragement of employees is made an unfair labor practice. ${ }^{37}$ This disparity of proscriptive language may indicate that although Congress intended to grant unhampered freedom of choice to employees, it intended to grant something less to the employer.

Of paramount importance in determining the scope of $8(\mathrm{e})$ is the language of the statute itself. ${ }^{38}$ Congress did not outlaw "all contracts or agreements limiting the freedom of the employer to handle the products of another employer"; it restricted its proscription to "express or implied" agreements not to handle such goods. ${ }^{39}$ It therefore manifested an intent to outlaw only those clauses which restrict employer freedom to such a degree that the fact finder could reasonably conclude that the restrictions were really intended by the contracting parties to constitute a veiled agreement not to handle. ${ }^{40}$

There may be a variety of clauses, therefore, which, while inclining the employer against handling hot goods, would fall short of the implied agreement proscription of $8(\mathrm{e})$. The following model clause, for example, could be included in a collective bargaining agreement:

Any employer covered by this contract may handle non-union goods upon, and only upon, payment to the_- union of - $\%$ of the money saved as a direct result of handling non-union, rather than union, goods, the amount of such savings to be ascertained by a mutually agreeable third party. ${ }^{41}$

son engaged in commerce ... to engage in, a strike or refusal ... to ... handle ... any goods ... or to perform any services; or (ii) to threaten, coerce, or restrain any person engaged in commerce ... where in either case an object thereof is ....

(B) forcing or requiring any person to cease ... dealing in the products of any other producer, processor, or manufacturer, or to cease doing business with any other person....

73 Stat. 542-43 (1959), 29 U.S.C. § 158(b) (4) (Supp. II 1961).

37. Ibid.

38. Most relevant, of course, is the very language in which Congress has expressed its policy and from which the Court must extract the meaning most appropriate.

Local 1976, United Bhd. of Carpenters v. NLRB, 357 U.S. 93, 100 (1958) (Frankfurter, J., speaking for the Court).

39. See note 1 supra.

40. In outlawing "implied" contracts and agreements, Congress was of course referring not to contracts "implied in law," or "quasi-contracts," but rather to so-called contracts "implied in fact."

The term "contract implied in fact" has traditionally been used to refer to a contract which is not formally or explicitly stated in words, but is rather inferred from the facts and circumstances of the case. 12 Am. Jur. Contracts $\$ 4$ (1938).

The term "implied" is used in law as contrasted with "express" when the "intention in regard to the subject matter is not manifested by explicit and direct words, but is gathered by implication or necessary deduction from the circumstances, the general language, or the conduct of the parties."

47 L.R.R.M. at 1378 (citing Black, LAw Dicrionary 888 (4th ed. 1951). See also Williston, Contracts $\$ 3$ (3d ed. 1957); Corbin, Contracts $\$ \$ 18-19$ (1950).

41. Admittedly, the determination of savings may be quite difficult. It is nearly impossible to ascertain what the cost of dealing with union employers would be where such 
If the percentage in such a "share the savings" clause were relatively small (say one or two percent), it would be clear to the contracting parties, under most circumstances, that the employer has not precluded himself from handling nonunion goods; it could not reasonably be argued, therefore, that such a clause constitutes an implied agreement not to handle. If, on the other hand, the percentage were relatively large (say 99 or 100 percent), it would be clear to the contracting parties that such a clause in practice leaves the employer no option to handle such goods, therefore constituting an implied agreement. ${ }^{42}$ If the percentage lay somewhere between these two extremes, the Board would have to make an empirical determination as to whether or not the clause, when coupled with other factors tending to incline the employer toward not handling non-union goods, and viewed against the background of the particular industry, is so restrictive that the contracting parties were aware that the employer would be left without a real option to handle such goods.

A "share the savings" clause, were it upheld by the Board, could, under certain circumstances, provide the union with much that the illegal hot cargo clause typically accomplished. The clause would help serve the organizational ends of the union since it would, to some degree, discourage the employer from dealing with non-union shops. ${ }^{43}$ It could also mitigate the impact of any loss of dues or pension contributions which might result to the union from the termination of some of its members' employment which may attend the employer's decision to buy from or subcontract to non-union shops.

Unions, under certain circumstances, might also find the following model clause of some organizational value:

Any employer covered by this contract may handle non-union goods only if at the time the agreement to handle was made, he has submitted to the union president a written statement listing the name(s) and location(s)

dealing is rare or sporadic. A possible method would be to examine the financial results of past union employer dealings, but costs, prices and overhead vary considerably from time to time and place to place, thus rendering comparison difficult at any time. Speculation as to what the economic benefit would be to the employer if he did not deal in "hot" goods is, therefore, seldom accurate, and, depending upon the outcome of such prediction, almost certainly would be unacceptable to either the employer or the union.

42. Quaere, whether an agreement that a given individual may engage in business if and only if he annually turns over $91 \%$ of his net profits to the other party constitutes an implied agreement not to engage in business? For answer, cf. INT. Rev. Code of 1954 (Tax-Rate Tables) p. iii (CCH 1961).

43. Occasionally, however, a clause of this nature may be viewed by an employer as union approval of dealing with non-union employers. Where the union exercises considerable influence, the employer may have refrained in the past from extensive dealings with nonunion employers because of the labor unrest which such activity might ignite. In such a situation, the clause may be construed by the employer as union authorization, at a price, of such dealings, and though less profits will accrue to him than would be derived from uninhibited handling of "hot" goods, he may conclude that the clause secures his lesser profits from union reprisal in the factory or at the bargaining table. Spurred on by this real or assumed security, the employer may in fact elect to increase his dealings with non-union employers, thereby creating a situation which, at best, can evoke from the union only mixed feelings. 
of the shop(s) from which the goods are to be bought, or to which they are to be subcontracted. ${ }^{44}$

This clause would be valuable only in industries, such as the garment ${ }^{45}$ and lithographic ${ }^{46}$ industries, where such factors as mobility of equipment, oversupply of labor, and availability of inexpensive operating locations render it relatively easy for non-union suppliers or subcontractors to disband and reestablish shops before the union can locate and attempt to organize them. In such industries union location of the "fly-by-night shops" is a precondition of organization. Although such a "tattletale clause" may, under certain circumstances, also weigh against an employer decision to handle hot goods, in that he would realize that organization of a non-union shop may dry up a source of inexpensive services, under most circumstances the obligation to disclose would not represent a restriction of employer freedom severe enough to constitute an implied agreement not to handle. ${ }^{47}$

The union in the present case claimed that the trade shop clause was motivated by a fear that an employer decision to subcontract to non-union shops work normally done by union members employed in his own shop would

44. This clause is similar not only to clauses contained in the bulk of the collective bargaining agreements in force in the garment industry, but also to section (d) of the trade shop clause. 47 L.R.R.M. at 1375.

45. LEGrs. Hisr. 1576, 1708, 1736.

46. Respondent's Brief 25, 36 .

The Amalgamated Lithographers attacked the exemption from 8(e) of the garment but not the lithographic industry as a denial of due process. This constitutional attack appears doomed. See Brown v. Local 17, Amalgamated Lithographers, 180 F. Supp. 294, 305-06 (N.D. Cal. 1960) and cases there cited. Nevertheless, extra-constitutional considerations may prove the distinction unfair as a matter of public policy.

The legislative history makes somewhat less than crystal clear just why the garment industry was exempted. Often mentioned was the fact that the industry is "integrated." LEGrs. Hrst. 1377, 1385, 1429, 1446, 1680. (The precise meaning of this term is not clear. The Amalgamated Lithographers claims the lithographic industry is integrated. Respondent's Brief 56. The Teamsters' lawyer claims the trucking industry is integrated. Previant, The New Hot-Cargo and Secondary-Boycott Sections: A Critical Analysis, 48 Gio. L.J. 346,352 (1959).) The ease with which "fly-by-night" non-union shops can be set up and disbanded also appears to have been taken into account. Id. at 1576, 1708, 1736. But whatever the rationale underlying the exemption was, it is clear that it was the duty of Congress to apply the policy underlying the exemption across the board-either by examining the factors present in other industries and specifically exempting appropriate industries, or by setting up general statutory standards by which the Board and courts could grant exemptions. Its failure to pursue either course suggests that the garment industry exemption was class legislation, a "reward" granted a "deserving" union (see LeGrs. HIst. 1429-30, 1729, 1732) just as the Senate attempt to ban hot cargo clauses only as to the Teamsters can be viewed as an attempted "punishment" of a "bad" union. See LeGrs. Hrst. 1858.

47. Of course, the restriction would depend upon such factors as whether the union already knew where the non-union shops were, whether the union could easily organize such shops if it knew their location, how much the shops' prices would be affected by organization, and whether there were enough non-union shops available to provide services if the shops with which the employer was dealing at the time were to organize. 
have adverse effects upon the union's pension and welfare funds. ${ }^{48} \mathrm{~A}$ clause prohibiting subcontracting entirely could, if held legal, end such apprehension. However, such a clause would be valuable only in a limited number of situations. It would not be practicable, for instance, in industries where employers would be financially unable, even if willing, to undertake performance of all the steps of the production process. ${ }^{49}$ And of course such a "no-subcontracting" clause ${ }^{\tilde{0} 0}$ could not protect the jobs of union members in industries where ownership of the goods changes as they pass through the production process. ${ }^{51}$ Although a no-subcontracting clause, where practicable, would preserve the jobs of union members and thereby protect the union's funds, it would not be as effective an organizational tool as clauses of the type proposed by the union. A clause whose prohibition singles out non-union employers would encourage such employers to permit unionization, but a blanket subcontracting ban offers no such incentive. ${ }^{52}$

It can be persuasively argued that a no-subcontracting clause would not violate $8(\mathrm{e}) .{ }^{53}$ Before the passage of the statute, the no-subcontracting clause was treated as wholly distinct from the hot cargo clause-the undoubted target of $8(\mathrm{e})$-which singles out for boycott only goods regarded by the union as "unfair." 54 Further, the classic rationale of the secondary boycott restrictions-the elimination of specified types of "coercion of neutral employers, themselves not concerned with a primary labor dispute"

48. Respondent's Brief 16.

49. There are also industries, such as the garment industry, where, even if such a shift were possible, union insistence that the entire process be performed in a single plant would necessitate a full-scale change in the manufacturing pattern of the industry. See LEGIS. HIST. 1385, 1680, 1818, 1829, 1857.

50. The term "no-subcontracting clause" is used to signify a clause forbidding all subcontracting, and not merely subcontracting to non-union or some other specific class of shops.

51. That is, such a clause could not prevent the loss of union members' jobs which would result from an employer's decision to buy goods he normally produces in his own plant.

52. Even if a non-union subcontractor were to unionize, a blanket clause would still forbid dealing with him. His only possible incentive would be the slim hope that his organizing might lead to an omission of the clause in the next contract. Thus, the fact that the trade shop clause was couched not in terms of prohibiting all subcontracting, but rather in terms which singled out the handling of non-union goods, suggests that the union's purpose was at least in part organizational.

53. Previant, The New Hot-Cargo and Secondary-Boycott Sections: A Critical Analysis, 48 Geo. L.J. 346, 355-56 (1959); Comment, 45 CoRNell L.Q. 724, 748-50 (1960); see also Cox, The Landrum-Griffin Amendments to the National Labor Relations Act, 44 Minn. I. Rev. 257, 273 (1959); Farmer, The Status and Application of the SecondaryBoycott and Hot-Cargo Provisions, 48 GEo. L.J. 327, 337-38 (1959).

54. Comment, 45 CoRnerr L.Q. 724, 750 (1960); see Cox, supra note 53, at 273.

55. Local 1976, United Bhd. of Carpenters v. NLRB, 357 U.S. 93, 100 (1958). See also NLRB v. Denver Bldg. \& Constr. Trades Council, 341 U.S. 675, 692 (1951) ; International Bhd. of Elec. Workers v. NLRB, 181 F.2d 34, 37 (2d Cir. 1950); 93 Cong. Kec. 4198 (1947) (remarks of Senator Taft); LEgrs. Hrst. 1197, 1425, 1633. 
it provides support for the outlawing of the hot cargo clause, does not provide such support for the prohibition of the no-subcontracting clause. Hot cargo clauses are designed to use the employer as a conduit through which the union may exert pressure on the "unfair" employers ;" but no-subcontracting clauses are primarily geared to insuring that the employer himself will not take action of a sort which will take jobs from members of the bargaining unit. But there remains the all-important fact that the no-subcontracting clause, being an express agreement that the employer will not deal with other employers, appears to violate the wording of $8(\mathrm{e}) .^{\mathbf{5 7}}$

Although the language of a statute, if it is not ambiguous, must be definitive of the outer limits of the statute's proscription, regardless of legislative history suggesting an intent to outlaw more than the language indicates, ${ }^{58}$ it can be forcefully argued that a statute need not be read to outlaw all that is contained within its proscriptive language, if the relevant history indicates that the language outlaws more than the legislature intended. ${ }^{59}$ The statute's function as "fair warning" demands that it not be read to proscribe anything beyond the limits of its language, for those who act upon the assumption that the statute means what it says should not be subjected to the possibility of unanticipated sanctions. However, this consideration generally does not militate against reading a statute to outlaw less than its language indicates, for such a reading would subject no one to such "unwritten proscription." Also,

56. See authorities cited at note 2 supra and accompanying text.

57. It has been argued that because 8 (e) specifically outlaws only agreements to "cease" (and not to "refrain from") "doing business with" other employers, the no-subcontracting clause is not illegal under $8(\mathrm{e})$. Previant, The New Hot-Cargo and Secondary-Boycott Scctions: A Critical Analysis, 48 Geo. L.J. 346, 354-56 (1959); Comment, 45 CoRnell L.Q. 724, 749 (1960).

Although this argument may give the Board a peg upon which to hang a finding that the no-subcontracting clause is legal, a fair reading of the entire statute would seem to compel the opposite conclusion. See Cox, The Landrum-Griffin Amendments to the National Labor Relations Act, 44 MnNN. L. REv. 257, 273 (1959). It would seem that a no-subcontracting clause is an agreement that the employer will not "deal in any of the products" of other employers. This agreement does come within the language of $8(\mathrm{e})$. See note 1 supra.

The argument described above establishes at most that the statute is ambiguous. For a discussion of the bearing of the legislative history on the meaning of the statute with respect to no-subcontracting clauses, see notes $61-63$ and accompanying text.

58. This was the approach taken by the Court in Sand Door:

Whatever may have been said in Congress preceding the passage of the Taft-Hartley Act concerning the evil of all forms of "secondary boycotts" and the desirability of outlawing them, it is clear that no such sweeping prohibition was in fact enacted in $\$ 8(\mathrm{~b}) 4(\mathrm{~A})$. The section does not speak generally of secondary boycotts. It describes and condemns specific union conduct directed to specific objectives.

Local 1976, United Bhd. of Carpenters v. NLRB, 357 U.S. 93, 98 (1958).

59. It was undoubtedly considerations of this sort that led the D.C. Circuit to conclude, in dictum contained in Ross v. Hartman, 139 F.2d 14, 15-16 n.10 (D.C. Cir. 1943), that an ordinance requiring the locking of parked cars did not apply in certain emergency situations. "A classic illustration of the same general principle is the Bologna ordinance against bloadletting in the streets, which did not make criminals of surgeons." Ibid. 
when proscriptive legislation is sought by certain individuals to achieve a broad, controversial end, but the ultimate language of the statute stops short of achieving that end, it must be presumed that the statute as enacted reflects the product of the various countervailing forces, and that the ultimate wording represents the strongest proscription to which a majority of the members of each of the ratifying bodies could be expected to assent. Mere inadvertence could scarcely account for the fact that the limits of the proscriptive language extend no further than they do. But, on the other hand, it is possible for Congress inadvertently to enact broadly proscriptive language without realizing that certain activities which no substantial segment of Congress desires to proscribe have thereby been outlawed by the wording of the statute along with those activities at which the statute was directed.

It may be argued that regardless of the general force of these considerations, they cannot support a conclusion that the no-subcontracting clause does not come within 8(e), for inadvertence can not account for the enactment of language which may be read to include such a clause. Senators Morse ${ }^{60}$ and Kennedy and Representative Thompson ${ }^{61}$ explicitly cautioned Congress that the language of $8(\mathrm{e})$ appears to prohibit the no-subcontracting clause. It can therefore be argued that since Congress failed to alter the proscriptive language of the statute or to exempt specifically such clauses therefrom, and since some of those voting for 8 (e) obviously intended thereby to outlaw no-subcontracting clauses, ${ }^{62}$ the Board and the courts must conclude that the statutory language must be read literally with respect to the no-subcontracting clause.

This argument overlooks the existence of a number of explanations for the failure to alter the statutory language, other than a desire on the part of Congress to outlaw the no-subcontracting clause. For instance, many Congressmen may have assumed that since $8(\mathrm{e})$ was aimed at the hot cargo clause, the Board and the courts would not apply it to something so dissimilar as a no-subcontracting clause. Others may have been swayed by a fear that any attempt to alter the statutory language so close to agreement and so late in the session might lead to more difficulties than benefits. It cannot be inferred from two "parade of horribles" warnings as to a possible construction of $8(\mathrm{e})$, that Congress intended, without any discussion or debate, to effect so major a change in the national labor policy as outright prohibition of the no-subcontracting clause. When a judicial agency, by employing traditional tools of statutory construction, ${ }^{63}$ can interpret a statute in either of two ways, it should be extremely hesitant to accept that interpretation which effects a major change of policy when there are serious doubts about whether the legislature intended to make such a change.

\footnotetext{
60. LeGIS. HIST. 1428.

61. LEGrs. HIST. 1708.

62. See Cox, supra note 53, at 273.

63. See note 59 supra.
} 